\title{
Editorial: Ecology and Behavior of Native, Naturalized, and Invasive Ladybird Beetles
}

\author{
Eric W. Riddick ${ }^{1 *}$ and António O. Soares ${ }^{2}$ \\ ${ }^{1}$ National Biological Control Laboratory, United States Department of Agriculture, Agricultural Research Service, Washington, \\ DC, United States, ${ }^{2}$ Azorean Biodiversity Group, Center for Ecology, Evolution and Environmental Changes, University of the \\ Azores, Ponta Delgada, Portugal
}

Keywords: behavior, biogeography, biological control, ecology, nutrition

\section{Editorial on the Research Topic}

Ecology and Behavior of Native, Naturalized, and Invasive Ladybird Beetles

Most ladybirds (Coleoptera: Coccinellidae) are predators of insects and mites (Giorgi et al., 2009; Weber and Lundgren, 2009). Their importance as biological control agents has been recognized for many years. With the advent of increased international travel and biological control operations aimed at controlling invasive herbivores, several species have been introduced (intentionally or unintentionally) into foreign countries. These introductions have had positive, neutral, or negative consequences. The aim of this research topic is to highlight studies on how invasive, native, and naturalized ladybirds expand their geographic range and also increase their fitness.

The impetus for this research topic of Frontiers in Ecology and Evolution sprang forth after a symposium of the same title was held at the XXV International Congress of Entomology, in

OPEN ACCESS

Edited and reviewed by: Jordi Figuerola, Estación Biológica de Doñana (EBD),

Spain

*Correspondence: Eric W. Riddick eric.riddick@ars.usda.gov

Specialty section:

This article was submitted to Behavioral and Evolutionary Ecology,

a section of the journal

Frontiers in Ecology and Evolution

Received: 17 July 2018

Accepted: 23 July 2018

Published: 10 August 2018

Citation:

Riddick EW and Soares AO (2018) Editorial: Ecology and Behavior of Native, Naturalized, and Invasive Ladybird Beetles.

Front. Ecol. Evol. 6:119 doi: 10.3389/fevo.2018.00119 Orlando, Florida, USA, in September 2016. The symposium was organized by Eric W. Riddick, Oldrich Nedvěd, Louis S. Hesler, Helen E. Roy, John J. Sloggett, and António O. Soares.

\section{OVERVIEW OF ARTICLES IN RESEARCH TOPIC}

This research topic consists of articles written by a diverse cadre of scientists in the USA, UK, Portugal, Germany, France, Czech Republic, China, and Belgium. Four articles focus exclusively on the ladybird Harmonia axyridis (Pallas), of Asian origin. One article focuses on a native ladybird Coccinella novemnotata Herbst (in North America) and the closely related Coccinella septempunctata L. of European origin, but now naturalized in some localities in North America. One article examines a range of coccinellid species, native and alien, including $H$. axyridis, in Europe.

The ladybird $H$. axyridis is one of the most effective predators of aphids and related pests in the world (Riddick, 2017). Sun and Liu tested the influence of prey color on predation rate and fitness gain of H. axyridis. They used the red and green morphs of the pea aphid (Acyrthosiphon pisum) in their bioassays against $H$. axyridis larvae and adults. Contrary to expectation, and rearing history, H. axyridis did not prefer the red A. pisum morph (more than the green morph) and there was no obvious fitness gain in consuming one morph over the other.

The physiological condition of ladybirds can have profound effects on their ability to withstand harsh environmental conditions, such as overwintering in cold climatic regions of the world. Facon et al. tested the effects of mating status on cold tolerance and reproduction of H. axyridis. They discovered that unmated females survived cold stress better than mated ones. Also, individuals that had mated, but not reproduced, prior to the cold stress, survived better than those that had 
reproduced. In addition, females that reproduced before the cold stress period were less likely to reproduce again, post cold stress. The authors suggest that $H$. axyridis females have a survival advantage when they enter overwintering aggregations in an unmated physiological state.

Verheggen et al. examined the behavioral and immunological characteristics of $H$. axyridis for clues to its superior invasive performance. The capacity of $H$. axyridis to utilize semiochemicals to establish and maintain overwintering aggregations, locate mates, locate prey, and defend themselves against natural enemies has contributed to its invasion success. Also, the possession of antimicrobial peptides in egg and larval stages provide protection from intraguild predators. The authors concluded that $H$. axyridis is well-equipped to outcompete native ladybird species in invaded countries.

Morphological defenses of a ladybird could help explain its invasion success. Hautier et al. tested the importance of dorsal spines on $H$. axyridis larvae as a defense against attacks from larvae of a European coccinellid species, C. septempunctata. The authors surgically removed the dorsal spines from test larvae and compared the frequency in which these amputated larvae were bitten by $C$. septempunctata larvae. In comparison to a control group (larvae with spines intact) and an injured group (larvae pricked with insect pins), the spineless larvae suffered more bites. The authors concluded that spines on $H$. axyridis larvae could contribute to their ability to defend themselves against intraguild predation in their invaded countries. This morphological defense could contribute to the expansion of $H$. axyridis into new areas.

Soares et al. compared the development rates and dispersal ability of ladybirds, native versus alien to Europe. They discovered that successful invaders were very adaptable to a wide range of geographic conditions. Although development rates were not significantly different between native and alien ladybird

\section{REFERENCES}

Giorgi, J. A., Vandenberg, N. J., McHugh, J. V., Forrester, J. A., Slipinski, S. A., Miller, K. B., et al. (2009). The evolution of food preferences in Coccinellidae. Biol. Control 51, 215-231. doi: 10.1016/j.biocontrol.2009. 05.019

Honěk, A., Dixon, A. F. G., Soares, A. O., Skuhrovec, J., and Martinkova, Z. (2017). Spatial and temporal changes in the abundance and composition of ladybird (Coleoptera: Coccinellidae) communities. Curr. Opin. Insect Sci. 20, 61-67. doi: 10.1016/j.cois.2017 .04 .001

Riddick, E. W. (2017). Spotlight on the positive effects of the ladybird Harmonia axyridis on agriculture. BioControl 62, 319-330. doi: 10.1007/s10526-016-9758-8 species, potential dispersal ability was higher for $H$. axyridis, the only aphidophagous ladybird considered as invasive in Europe.

Intentional or unintentional releases of the highly competitive C. septempunctata into the intermountain regions of western North America might have caused declines in population density of rare, native species, such as C. novemnotata. In a field study spanning three decades, Evans examined C. novemnotata and C. septempunctata populations in a diversity of plant communities. He found that $C$. novemnotata persisted at low densities over the time period. There was no convincing evidence that $C$. septempunctata reduced $C$. novemnotata populations. Evans suggests that the ability of $C$. novemnotata to exploit food resources in diverse habitats across a heterogenous landscape has contributed to its persistence, albeit at low densities, despite the establishment of C. septempunctata.

\section{Future Directions}

With increased agricultural commerce and trade between countries (and continents), the intentional or unintentional introduction of ladybirds will likely increase. These introductions could have positive or negative effects. Positive effects would include increased suppression of plant pests in agricultural systems. Negative effects may involve reduction of populations of native species driven by competitive interactions. Most likely, future research will depend on multinational teams of scientists (entomologists, ecologists, and chemists) aiming to test hypotheses on the main drivers of variation in the composition of ladybird communities, including agricultural and habitat changes, invasions, and climatic changes (Honěk et al., 2017).

\section{AUTHOR CONTRIBUTIONS}

The authors ER and AS contributed equally to this work and approved it for publication.

Weber, D. C., and Lundgren, J. G. (2009). Assessing the trophic ecology of the Coccinellidae: their roles as predators and as prey. Biol. Control 51, 199-214. doi: 10.1016/j.biocontrol.2009.05.013

Conflict of Interest Statement: The authors declare that the research was conducted in the absence of any commercial or financial relationships that could be construed as a potential conflict of interest.

Copyright (c) 2018 Riddick and Soares. This is an open-access article distributed under the terms of the Creative Commons Attribution License (CC BY). The use, distribution or reproduction in other forums is permitted, provided the original author(s) and the copyright owner(s) are credited and that the original publication in this journal is cited, in accordance with accepted academic practice. No use, distribution or reproduction is permitted which does not comply with these terms. 